\title{
Biodegradation of Emerging Pharmaceuticals from Domestic Wastewater by Membrane Bioreactor: The Effect of Solid Retention Time
}

\author{
Raghad Asad Kadhim ALOBAIDI ${ }^{1,2, * \mathbb{C}}$, Kubra ULUCAN-ALTUNTAS ${ }^{1, *(\mathbb{D}}$, Rasha Khalid Sabri MHEMID ${ }^{3}$, \\ Neslihan MANAV-DEMIR ${ }^{1}$ and Ozer CINAR ${ }^{1}[$
}

check for updates

Citation: ALOBAIDI, R.A.K.; ULUCAN-ALTUNTAS, K.; MHEMID, R.K.S.; MANAV-DEMIR, N.; CINAR,

O. Biodegradation of Emerging Pharmaceuticals from Domestic Wastewater by Membrane Bioreactor: The Effect of Solid Retention Time. Int. J. Environ. Res. Public Health 2021, 18, 3395. https://doi.org/10.3390/ ijerph18073395

Academic Editor: Paul B. Tchounwou

Received: 25 February 2021

Accepted: 17 March 2021

Published: 25 March 2021

Publisher's Note: MDPI stays neutral with regard to jurisdictional claims in published maps and institutional affiliations.

Copyright: (c) 2021 by the authors. Licensee MDPI, Basel, Switzerland. This article is an open access article distributed under the terms and conditions of the Creative Commons Attribution (CC BY) license (https:/ / creativecommons.org/licenses/by/ $4.0 /)$.
1 Department of Environmental Engineering, Faculty of Civil Engineering, Yildiz Technical University, Istanbul 34220, Turkey; nmanav@yildiz.edu.tr (N.M.-D.); ocinar@yildiz.edu.tr (O.C.)

2 Ministry of Health and Environment, Baghdad, Iraq

3 Department of Environmental Technologies, College of Environmental Science and Technologies, Mosul University, Mosul 41002, Iraq; rashamhemid@uomosul.edu.iq

* Correspondence: env.alobaidi@yahoo.com (R.A.K.A.); kulucan@yildiz.edu.tr (K.U.-A.)

\begin{abstract}
Although conventional biological treatment plants can remove basic pollutants, they are ineffective at removing recalcitrant pollutants. Membrane bioreactors contain promising technology and have the advantages of better effluent quality and lower sludge production compared to those of conventional biological treatment processes. In this study, the removal of pharmaceutical compounds by membrane bioreactors under different solid retention times (SRTs) was investigated. To study the effect of SRT on the removal of emerging pharmaceuticals, the levels of pharmaceuticals were measured over 96 days for the following retention times: 20, 30, and 40-day SRT. It was found that the 40-day SRT had the optimum performance in terms of the pharmaceuticals' elimination. The removal efficiencies of the chemical oxygen demand (COD) for each selected SRT were higher than $96 \%$ at steady-state conditions. The highest degradation efficiency was observed for paracetamol. Paracetamol was the most removed compound followed by ranitidine, atenolol, bezafibrate, diclofenac, and carbamazepine. The microbial community at the phylum level was also analyzed to understand the biodegradability of pharmaceuticals. It was noticed that the Proteobacteria phylum increased from $46.8 \%$ to $60.0 \%$ after 96 days with the pharmaceuticals. The Actinobacteria class, which can metabolize paracetamol, carbamazepine, and atenolol, was also increased from $9.1 \%$ to $17.9 \%$ after adding pharmaceuticals. The by-products of diclofenac, bezafibrate, and carbamazepine were observed in the effluent samples.
\end{abstract}

Keywords: biodegradation; solid retention time; pharmaceuticals; membrane bioreactor; solid-phase extraction; by-products

\section{Introduction}

The increase in the use of micropollutants, including pharmaceuticals, has become a major environmental problem in recent years. While the presence of pharmaceutical compounds is limited in the environment, knowledge of the long-term threats to aquatic species and human health even with low levels of drugs remains lacking. The concentration and effects of micropollutants on the environment and, perhaps, human beings have increased over the past few decades. Many micropollutants are persistent, only partially removed during treatment, and when disposed of in the environment over a long period, cause substantial pollution. The European directive, Water Framework Directive 2000/60/EC, is a global framework that underlines the importance of micropollutants in superficial water (rivers and lakes), transitional water (estuaries), coastal waters, and groundwater.

Although traditional water and wastewater treatment plants are successful in controlling pollutants such as organic substances and nutrients, they cannot remove the 
micropollutants (MPs). These micropollutants are substances found in low concentrations (ng/L and $\mu \mathrm{g} / \mathrm{L}$ ) in water and wastewater and consist of metals, hydrocarbons, surfactants, hormones, and pharmaceutical products. According to many studies, conventional wastewater treatment systems are insufficient to degrade certain pharmaceutical compounds, as a result, these compounds can be found in surface and groundwater [1-3]. In particular, pharmaceutical compounds are biologically active compounds that affect microorganisms upon their discharge to the aquatic environment. They are recalcitrant compounds that take a long time to break down in nature, therefore, effective methods of wastewater treatment that allow for the efficient removal of emerging pollutants at trace levels are increasingly needed. In wastewater treatment, MBR (membrane bioreactor) systems have been used more commonly recently because of their high effluent quality performance [4]. MBRs are effective in the treatment of many organic and inorganic pollutants, offering three basic advantages: (i) enhanced adsorption capacities through improved biomass characteristics; (ii) improved high sludge biodegradation, (iii) direct removal of several contaminants adsorbed on rejected particles through the membrane [5]. These process benefits are commonly recognized over the those of the traditional activated sludge process [6]; the most cited benefit is the decrease of sludge production resulting from operation at high solid retention times (SRTs). In general, hydrophobic and readily-biodegradable contaminants are very effectively eliminated by MBRs. However, hydrophilic compounds, in particular biodegradation-resistant ones, may not be excluded [7]. The substantial difference in MBR removal efficiency for several pharmaceuticals, from near-complete removal (e.g., paracetamol and bezafibrate) to almost no removal for some others (for example, carbamazepine and diclofenac) [8-10], has been noted previously.

Removal mechanisms do not follow a general rule as their relative contribution is dependent on the physicochemical properties of the micropollutant, its origin and composition, and the wastewater operational parameters [11]. A significant point is to understand why the removal of micropollutants such as pharmaceuticals by MBRs are affected by the treatment conditions applied in terms of the solid retention time (SRT). A single compound may vary in removal rate and this may be correlated with the physicochemical characteristics of the xenobiotics.

Various analytical determination methods of pharmaceutical compounds in wastewater are already available in the literature, which records specific pharmaceutical existence at levels from ng/L to g/L [12]. Multi-residual analytical methodologies, including pharmaceutical products of the multi-class range, are the tools required to provide a reliable and broad knowledge base on the presence of pharmaceuticals and for monitoring their removal, partitioning, and final fate. When analyzing several different physicochemical compounds simultaneously, a high recovery rate for each compound may not be seen. Therefore, a common experimental condition must be determined. However, the creation of the multicomponent analysis method is useful due to the reduced number of analyses that are required. The pre-concentration and isolation of the goal analytes can be performed by solid-phase extraction (SPE). The determination of the overall SPE method is important because most of these multicomponent analysis methods consist of two or more different sorbent materials and solvents used for elution, and they involve grouping target compounds according to their physicochemical properties.

Given these facts, the purpose of this work was the development of a sensitive multicomponent solid-phase extraction method to simultaneously analyze, by LC/MS-MS, six different therapeutic classified pharmaceuticals in synthetic domestic wastewater and to investigate the influences of SRT on treatment performance of the MBR in terms of removing these pharmaceuticals from synthetic domestic wastewater. The change in microbial species due to the micropollutants was also studied. 


\section{Materials and Methods}

\subsection{Design of the MBR System and Its Operation}

The reactor was constructed according to the design and configuration for the size and dimensions of the membrane modules equipped with two PES (polyethersulfone) membranes with $0.45 \mu \mathrm{m}$ and $0.20 \mu \mathrm{m}$ pore sizes (Sterlitech Cooperation, Kent, WA, USA).

The aerobic membrane bioreactor was made of a plexiglass material with a cylindrical shape of $17.5 \mathrm{~cm}$ diameter corresponding to an $8 \mathrm{~L}$ volume and an active operating volume of $4 \mathrm{~L}$. The peristaltic pumps were used to provide pressure for maintaining constant permeate flux and for automatic inoculation of the reactor feed (Shenchen Cooperation, Baoding, China). A level sensor was used to balance the water level of the reactor (Tin Muhendislik, Istanbul, Turkey). The reactor's oxygen demand was provided by ambient air through the air pumps and diffusers. Details of the reactor configuration are illustrated in Figure 1.

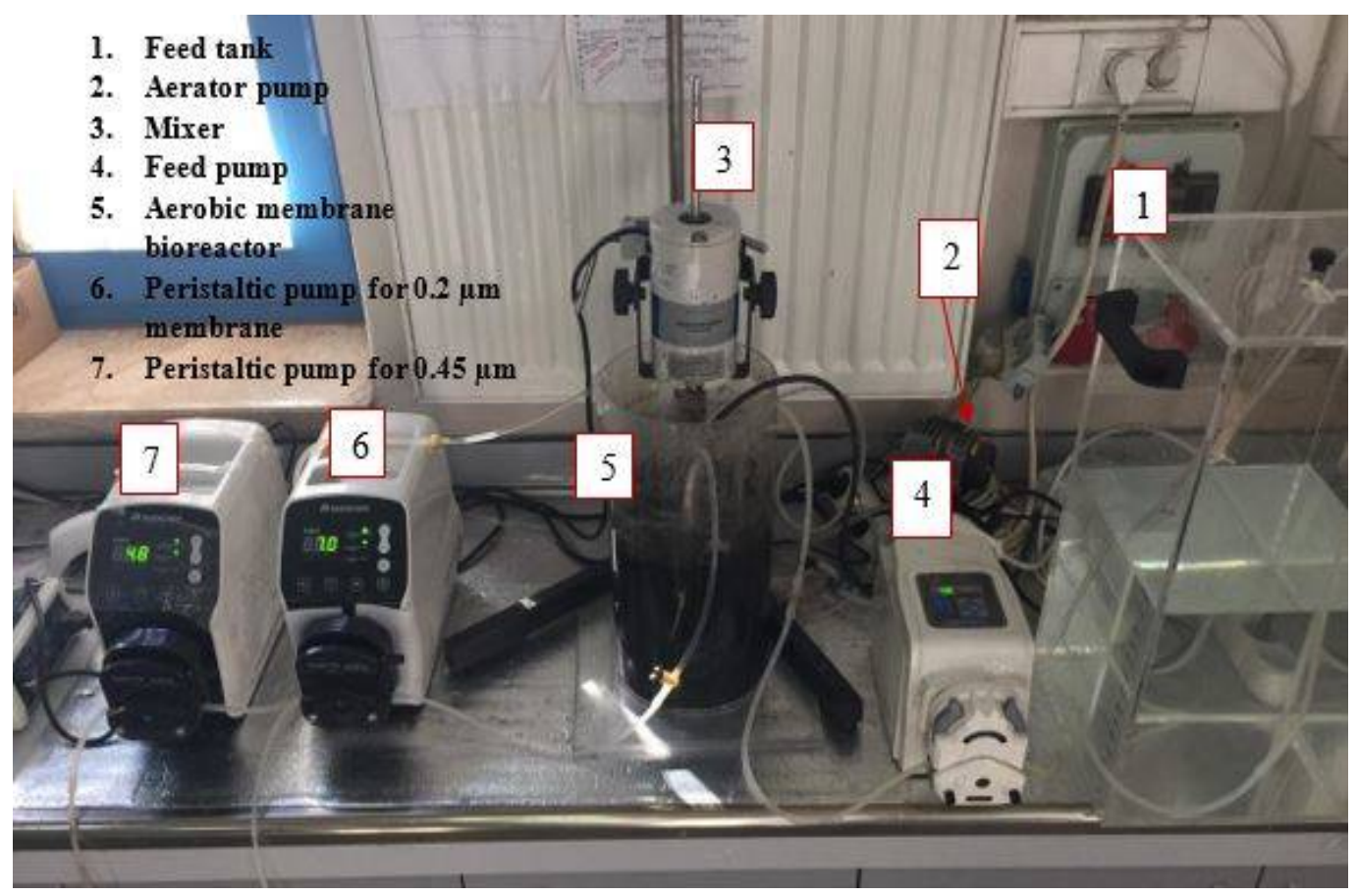

Figure 1. Lab-scale set up for submerged membrane bioreactor.

The aerobic submerged membrane bioreactor (AeSMBR) was fed with synthetic domestic wastewater prepared according to the following recipe: $50 \mathrm{mg} \cdot \mathrm{L}^{-1} \mathrm{NH}_{4} \mathrm{CI}$, $0.04 \mathrm{mg} \cdot \mathrm{L}^{-1} \mathrm{MnCI}_{2} \cdot 4 \mathrm{H}_{2} \mathrm{O}, 0.132 \mathrm{mg} \cdot \mathrm{L}^{-1} \mathrm{ZnCl}_{2}, 4.5 \mathrm{mg} \cdot \mathrm{L}^{-1} \mathrm{~K}_{2} \mathrm{HPO}_{4}, 4.2 \mathrm{mg} \cdot \mathrm{L}^{-1} \mathrm{KH}_{2} \mathrm{PO}_{4}$, $0.2 \mathrm{mg} \cdot \mathrm{L}^{-1} \mathrm{Na}_{2} \mathrm{SO}_{3} \cdot 5 \mathrm{H}_{2} \mathrm{O}, 0.1 \mathrm{mg} \cdot \mathrm{L}^{-1} \mathrm{CuCl}_{2} \cdot 2 \mathrm{H}_{2} \mathrm{O}, 2 \mathrm{mg} \cdot \mathrm{L}^{-1} \mathrm{FeCl}_{3} \cdot 6 \mathrm{H}_{2} \mathrm{O}, 0.1 \mathrm{mg} \cdot \mathrm{L}^{-1}$ $\mathrm{NiCl}_{2} \cdot 6 \mathrm{H}_{2} \mathrm{O}, 0.03 \mathrm{mg} \cdot \mathrm{L}^{-1} \mathrm{CoCl}_{2} \cdot 6 \mathrm{H}_{2} \mathrm{O}, 4.4 \mathrm{mg} \cdot \mathrm{L}^{-1} \mathrm{CaCl}_{2} \cdot 2 \mathrm{H}_{2} \mathrm{O}, 12.2 \mathrm{mg} \cdot \mathrm{L}^{-1} \mathrm{MgSO}_{4} \cdot 7 \mathrm{H}_{2} \mathrm{O}$, and $40 \mathrm{mg} \cdot \mathrm{L}^{-1}$ peptone. To obtain a $750 \mathrm{mg} \cdot \mathrm{L}^{-1}$ concentration of chemical oxygen demand (COD), glucose was added. The membrane tank was equipped with two polyethersulfones (PES) submerged flat sheet microfiltration modules, one with a pore size of $0.45 \mu \mathrm{m}$ and the other with a pore size $0.20 \mu \mathrm{m}$. Each membrane module comprised $12 \times 12 \mathrm{~cm}$ plexiglass, withan active surface area of $56.25 \mathrm{~cm}^{2}(7.5 \times 7.5 \mathrm{~cm})$.

As defined in fluid mechanics, flux is the volume of a fluid passing through a unit area at a specific time. In this context, flux can be formulated as:

$$
J=\frac{(\text { Volume })}{(\text { Time } \times \text { Area })}
$$


To provide adequate relaxation time for the membrane, the reactor was operated for $4.5 \mathrm{~min}$ and stopped for $30 \mathrm{~s}$. In this respect, the flux value needed to be recalculated by considering the relaxation time so that the net flux calculations could be rearrange as below:

$$
\text { Net Flux }=\frac{\text { Flux } \times \text { Running Time }}{\text { Waiting time }+ \text { Running Time }}=\frac{11.11 \times 4.5 \mathrm{~min}}{(0.5+4.5) \mathrm{min}} \cong 10 \mathrm{LMH}
$$

\subsection{Samples Preparation}

The target compounds were chosen because of their prevalence in the aquatic environment worldwide, ubiquity, and high human intake. Target compounds were categorized as shown in Table 1 according to their therapeutic effect and physicochemical properties.

Table 1. Main characteristics of the selected and analyzed pharmaceuticals $[13,14]$.

\begin{tabular}{|c|c|c|c|c|c|c|}
\hline & Carbamazepine & $\begin{array}{l}\text { Acetaminophen } \\
\text { (Paracetamol) }\end{array}$ & $\begin{array}{l}\text { Diclofenac } \\
\text { (Sodium Salt) }\end{array}$ & Bezafibrate & $\begin{array}{c}\text { Ranitidine } \\
\text { Hydrochloride }\end{array}$ & Atenolol \\
\hline Applications & Antiepileptic & Therapeutic & $\begin{array}{c}\text { Anti- } \\
\text { inflammatory }\end{array}$ & Lipid regulator & Anti-histamine & $\beta$-Blockers \\
\hline CAS Number & $298-46-4$ & $103-90-2$ & $15307-86-5$ & $41859-67-0$ & $66357-59-3$ & $29122-68-7$ \\
\hline Formula & $\mathrm{C}_{15} \mathrm{H}_{12} \mathrm{~N}_{2} \mathrm{O}$ & $\mathrm{C}_{8} \mathrm{H}_{9} \mathrm{NO}_{2}$ & $\mathrm{C}_{14} \mathrm{H}_{10} \mathrm{Cl}_{2} \mathrm{NNaO}_{2}$ & $\mathrm{C}_{19} \mathrm{H}_{20} \mathrm{ClNO}_{4}$ & $\mathrm{C}_{13} \mathrm{H}_{22} \mathrm{~N}_{4} \mathrm{O}_{3} \mathrm{~S} \cdot \mathrm{HCl}$ & $\mathrm{C}_{14} \mathrm{H}_{22} \mathrm{~N}_{2} \mathrm{O}_{3}$ \\
\hline $\log K_{o w}$ & 2.45 & 0.46 & 4.51 & 4.25 & 0.27 & 0.16 \\
\hline $\mathrm{pK}_{\mathrm{a}}$ & 13.9 & 9.4 & 4.15 & 3.61 & 8 & 9.6 \\
\hline $\log D$ & 1.89 & 0.47 & 1.77 & -0.93 & -0.63 & -2.09 \\
\hline $\begin{array}{l}\text { Henry Constant } \\
\left(\mathrm{atm}-\mathrm{m}^{3} / \mathrm{mole}\right)\end{array}$ & $1.1 \times 10^{-12}$ & $6.42 \times 10^{-13}$ & $4.7 \times 10^{-12}$ & $2.12 \times 10^{-15}$ & $3.42 \times 10^{-15}$ & $1.37 \times 10^{-18}$ \\
\hline M.W. & 236.27 & 151.17 & 318.14 & 361.82 & 350.86 & 266.34 \\
\hline $\begin{array}{l}\text { Molecular } \\
\text { Structure }\end{array}$ & & & & & & \\
\hline
\end{tabular}

All pharmaceutical standards used were of high purity grade (>98\%). Diclofenac, acetaminophen, bezafibrate, carbamazepine, ranitidine hydrochloride, and atenolol were purchased from Alfa Aesar (Kandel, Germany). The method developed consisted of one extraction step for all target compounds, which greatly simplified sample preparation. Individual standard stock solutions in ethanol were prepared based on weight and stored at $-2{ }^{\circ} \mathrm{C}$. An acceptable dilution of individual stock solutions was established for a mixture of all pharmaceuticals.

According to the literature review [15-18], the concentrations of this study analytes was chosen as $12 \mu \mathrm{g} / \mathrm{L}$ carbamazepine, $20 \mu \mathrm{g} / \mathrm{L}$ diclofenac, $20 \mu \mathrm{g} / \mathrm{L}$ atenolol, $20 \mu \mathrm{g} / \mathrm{L}$ ranitidine hydrochloride, $12 \mu \mathrm{g} / \mathrm{L}$ bezafibrate, and $100 \mu \mathrm{g} / \mathrm{L}$ acetaminophen (paracetamol).

\subsection{Solid-Phase Extraction Method}

Development, optimization, and validation of a method followed by liquid chromatography-triple quadrupole mass spectrometry (LC/MS-MS) were performed for the simultaneous determination of six multi-class pharmaceuticals using offline solid-phase extraction (SPE). The SPE method was inspired by the literature [19]. For conditioning applications, acetone (HPLC grade), methanol (HPLC grade), and ultrapure water were used (Merck, Istanbul, Turkey). Table 2 shows the conditions that were applied, including conditioning, percolation, washing, drying, and elution. 
Table 2. Solid-phase extraction (SPE) method determination.

\begin{tabular}{|c|c|c|c|c|}
\hline Applications & $\begin{array}{c}\text { SPE } \\
\text { Method } 1\end{array}$ & $\begin{array}{c}\text { SPE } \\
\text { Method } 2\end{array}$ & $\begin{array}{c}\text { SPE } \\
\text { Method } 3\end{array}$ & $\begin{array}{c}\text { SPE } \\
\text { Method } 4\end{array}$ \\
\hline $\begin{array}{l}\text { Types of } \\
\text { cartridge }\end{array}$ & $\begin{array}{l}\text { Oasis HLB } \\
\text { cartridge } \\
200 \mathrm{mg}, 6 \mathrm{~mL}\end{array}$ & $\begin{array}{c}\text { Oasis HLB } \\
\text { cartridge } \\
200 \mathrm{mg}, 6 \mathrm{~mL}\end{array}$ & $\begin{array}{l}\text { C18 cartridge, } \\
500 \mathrm{mg}, 6 \mathrm{~mL}\end{array}$ & $\begin{array}{l}\text { C18 cartridge, } \\
500 \mathrm{mg}, 6 \mathrm{~mL}\end{array}$ \\
\hline Conditioning & $\begin{array}{l}5 \mathrm{~mL} \mathrm{MeOH}, \\
5 \mathrm{~mL} \text { water }\end{array}$ & $\begin{array}{c}5 \mathrm{~mL} \text { acetone, } \\
5 \mathrm{~mL} \mathrm{MeOH}, \\
5 \mathrm{~mL} \text { water }\end{array}$ & $\begin{array}{c}5 \mathrm{~mL} \mathrm{MeOH}, \\
5 \mathrm{~mL} \text { water }\end{array}$ & $\begin{array}{c}5 \mathrm{~mL} \text { acetone, } \\
5 \mathrm{~mL} \mathrm{MeOH}, \\
5 \mathrm{~mL} \text { water }\end{array}$ \\
\hline Percolation & $100 \mathrm{~mL}$ & $100 \mathrm{~mL}$ & $100 \mathrm{~mL}$ & $100 \mathrm{~mL}$ \\
\hline Washing & $\begin{array}{l}5 \mathrm{~mL} \\
\text { water }\end{array}$ & $\begin{array}{l}5 \mathrm{~mL} \\
\text { water }\end{array}$ & $\begin{array}{l}5 \mathrm{~mL} \\
\text { water }\end{array}$ & $\begin{array}{l}5 \mathrm{~mL} \\
\text { water }\end{array}$ \\
\hline Drying & $15 \mathrm{~min}$. & $15 \mathrm{~min}$. & $15 \mathrm{~min}$. & $15 \mathrm{~min}$. \\
\hline Elution & $8 \mathrm{~mL} \mathrm{MeOH}$ & $8 \mathrm{~mL} \mathrm{MeOH}$ & $8 \mathrm{~mL} \mathrm{MeOH}$ & $8 \mathrm{~mL} \mathrm{MeOH}$ \\
\hline
\end{tabular}

To concentrate the samples, the compounds were extracted via the cartridges given in Table 2 using the SPE manifold system equipped with a vacuum pump. To optimize the extraction method, the performances of various SPE cartridge materials (Oasis HLB (200 mg, $6 \mathrm{~mL}$ ) from Waters Corporation and C18 (500 mg, $6 \mathrm{~mL}$ ) from Agilent) were compared. The detailed procedure is summarized in Table 2; firstly, SPE cartridges for samples 1 and 3 were conditioned with $5 \mathrm{~mL} \mathrm{MeOH}$ followed by $5 \mathrm{~mL}$ distilled water at a flow rate of $1 \mathrm{~mL} / \mathrm{min}$. The same procedure was applied for the conditioning of SPE cartridges for samples 2 and 4 but it was proceeded with a conditioning of $5 \mathrm{~mL}$ of acetone. The water samples were percolated by the cartridges following the conditioning stage. The cartridge was then rinsed with $5 \mathrm{~mL}$ HPLC-grade water and dried for 15 min under a vacuum to extract the excess water. Elution of $2 \times 4 \mathrm{~mL}$ of methanol was performed. For direct testing by LC/MS-MS analysis, the extract was evaporated under a gentle nitrogen stream and concentrated into $1 \mathrm{~mL}$ of sample volume.

\subsection{Analytical Methods}

The feed wastewater characterization and reactor performance were monitored by wet analyses. For the suspended solid (TSS) parameter, standard methods (APHA, 1998) were applied. COD is one of the most important parameters in determining the degree of organic pollution in wastewaters. COD analyses were carried out using the microdigestion and titration method specified in the standard methods (SM 5220B) [20].

An HPLC (Shimadzu) equipped with a Diode-Array Detection (DAD) detector and LC-QTOF-MS/MS (Agilent 6530 Accurate Mass-ESI Interface, Santa Clara, CA, USA) was used for liquid chromatography analysis. To achieve the chromatographic separation, the Purospher Star RP-18 column $(125 \mathrm{~mm} \times 2.0 \mathrm{~mm}$, particle size $5 \mu \mathrm{m})$ was supplied with a C18 guard column by Merck (Darmstadt, Germany). The analyses were performed in Positive Ionization mode with eluent A (acetonitrile-methanol (2:1)) and eluent B (ammonium acetate $5 \mathrm{mM}$ at pH 4.7 (acetic acid)). The flow rate was selected as $0.3 \mathrm{~mL} / \mathrm{min}$, and the injection volume was determined as $10 \mu \mathrm{L}$. According to the selected method, the eluent gradient started from $5 \%$ and rose to $95 \%$ of eluent A in $5 \mathrm{~min}$ (was held for $4 \mathrm{~min}$ ) and turned to the initial condition in $5 \mathrm{~min}$.

\subsection{Metagenomic Analysis}

Biomass samples at the beginning of the steady-state of the 40-day SRT (before adding pharmaceuticals) and at the end of the 40-day SRT (after adding pharmaceuticals) in the aerobic membrane bioreactor were collected and stored immediately at $-4{ }^{\circ} \mathrm{C}$ to evaluate the percentage of the microbial community. The samples were processed and analyzed as explained below. 


\subsection{DNA Isolation}

The samples with an amount of $200 \mathrm{mg}$ were transferred to tubes containing $0.1 \mathrm{~mm}$ diameter glass beads and $300 \mu \mathrm{L}$ of lysis buffer (200 mM Tris-HCl, pH 8.0; 20 mM EDTA; $10 \%$ TritonX-100) and were homogenized for $1 \mathrm{~min}$ at $6000 \mathrm{rpm}$. The samples were transferred to new tubes to isolate the beads and were incubated at the $37^{\circ} \mathrm{C}$ for $15 \mathrm{~min}$; then, $10 \mu \mathrm{L}$ of the lysozyme solution $(200 \mu \mathrm{g} / \mu \mathrm{L})$ was added. Next, $250 \mu \mathrm{L}$ of lysis buffer $\left(0.5 \mu \mathrm{g} / \mu \mathrm{L}\right.$ Proteinase $\mathrm{K}, 5 \%$ Tween $^{\circledR}$ 20, 3M Guanidine thiocyanate, $20 \mathrm{mM}$ Tris- $\mathrm{HCl}$, $\mathrm{pH}$ 8.0) was added to each sample, and the samples were incubated for $15 \mathrm{~min}$ at $70{ }^{\circ} \mathrm{C}$, followed by $5 \mathrm{~min}$ at $95{ }^{\circ} \mathrm{C}$. After incubation, $250 \mu \mathrm{L}$ of 2-propanol was appended to each tube and the samples were loaded onto the silica column. The DNA in the samples were passed through the silica column by centrifugation at 13,000 rpm for 1 min and kept by the silica column, then they were washed twice with wash solution $(20 \mathrm{mM} \mathrm{NaCl}, 2 \mathrm{mM}$ Tris- $\mathrm{HCl}, \mathrm{pH} 8 ; 80 \% v / v$ ethanol). The silica column was dried by centrifugation. DNA retained in the silica columns was taken from the columns with $50 \mu \mathrm{L}$ of $100 \mathrm{mM}$ Tris- $\mathrm{HCl}$ prepared with nuclease-free, sterile, deionized water $(\mathrm{pH} 7)$ and preserved at $-20{ }^{\circ} \mathrm{C}$ until analysis. Spectrophotometric methods measured the quantity and consistency of the DNA and checked its suitability for the following steps. Other molecular processes were performed using DNA with an OD260/OD280 ratio of 1.8-2.0, an OD260/OD230 ratio of $2.0-2.2$, and at least ten $\mathrm{ng} / \mu \mathrm{L}$ (preferably $50-300 \mathrm{ng} / \mu \mathrm{L}$ ) concentration.

\subsection{Next Generation Sequencing (NGS)}

The primary pair was used to create amplicon libraries that covered about a $460 \mathrm{bp}$ region and the V3-V4 region of the 16S rRNA gene [21]. Connector DNA sequences were added to the $5^{\prime}$ end of the target-specific primer pairs for compatibility with the Illumina index and sequence adapters of the generated library. The forward primer sequence of the primer-connector oligos specific for 16Sr RNA was $5^{\prime}$ TCGTCGGCAGCGTCAGATGTGTATAAGAGACAGCCTACGGGNGGCWGCAG $3^{\prime}$, and the reverse primer sequence was $5^{\prime}$ GTCTCGTGGGCTCGGAGATGTGTATAAGAGACAGGACTACHVGGGTATCT AATCC-3'. The first PCR step was performed using "Bio-Speedy ${ }^{\circledR} 2 \mathrm{X}$ qPCR Mix" and $200 \mathrm{~nm}$ from each primer.

The following thermal cycling program was monitored on the Biorad CFX Connect (Bio-Rad, Hercules, CA, USA): 3 min at $95{ }^{\circ} \mathrm{C} ; 25$ cycles of $30 \mathrm{~s}$ at $95{ }^{\circ} \mathrm{C}, 30 \mathrm{~s}$ at $55^{\circ} \mathrm{C}$, and $30 \mathrm{~s}$ at $72{ }^{\circ} \mathrm{C} ; 5 \mathrm{~min}$ at $72{ }^{\circ} \mathrm{C}$. By carrying out agarose gel electrophoresis of the PCR, the product size ( $\sim 550 \mathrm{bp})$ was confirmed and "Bio-Speedy ${ }^{\circledR}$ PCR Product Cleaning Kit" (Bioeks, Istanbul, Turkey) was used as an eluent.

By performing the second PCR step, binary index and Illumina sequencing adapters were included in the first PCR amplicons by using the Nextera XT Index Kit (Illumina, New York, NY, USA) then, the following program was used for thermal cycling: $95^{\circ} \mathrm{C}$ for $3 \mathrm{~min}$; 8 cycles of $30 \mathrm{~s}$ at $95^{\circ} \mathrm{C}, 30 \mathrm{~s}$ at $55^{\circ} \mathrm{C}$, and $30 \mathrm{~s}$ at $72{ }^{\circ} \mathrm{C} ; 5 \mathrm{~min}$ at $72{ }^{\circ} \mathrm{C}$. PCR products were cleaned up with a "Bio-Speedy ${ }^{\circledR}$ PCR Product Cleaning Kit" (Bioeks, Istanbul, Turkey). The final library was checked for size ( 630 bp) by using the "Bioanalyzer DNA 1000 chip". To form a library pool, the final library was diluted to $4 \mathrm{nM}$ using $10 \mathrm{mM}$ Tris $\mathrm{pH} 8.5$ and $5 \mu \mathrm{L}$ aliquots.

The collected libraries were denatured with $\mathrm{NaOH}$, diluted with hybridization buffer (HT1), and denatured by temperature for batch forming and sequencing preparation, before the MiSeq sequencing. The research was performed using Illumina MiSeq v3 reaction kits. For each reaction, as an internal control, a minimum of 5\% PhiX was added.

Mothur version 1.39.1 was used to examine the unprocessed sequence data (forward and reverse reads merged). The first step was to cut out the index and main sequences and then classify the particular sequences. The trimmed unique sequences were aligned using the RDP database sequences and the blastn algorithm. Filtering and error checking were done to unaligned sequences at both ends of the sequences. Pollution was prevented by pre-clustering. The UCHIME [22] code was used for the chimera removal. The sequences were categorized using the Bayesian classifier built into Mothur. With the support of the 
RDP database, reference and taxonomy files were gained. After the operational taxonomic unit (OTU) was selected and taxonomic determination was made according to the RDP database, OTUs were grouped according to their phylotypes.

\section{Results}

\subsection{Determination of the SPE Method}

To analyze the selected compound by LC/MS-MS, the selected compounds were required to be concentrated by the solid-phase extraction method: different solvents and cartridges were compared for their recoveries. The summarized methods are given in Table 2. The concentrations of atenolol, ranitidine, paracetamol, carbamazepine, bezafibrate, and diclofenac were 20, 20, 100, 12, 12, and, $20 \mu \mathrm{g} / \mathrm{L}$, respectively. The volume of the samples used to analyze recoveries was $100 \mathrm{~mL}$. The calculated recoveries can be seen in Figure 2.

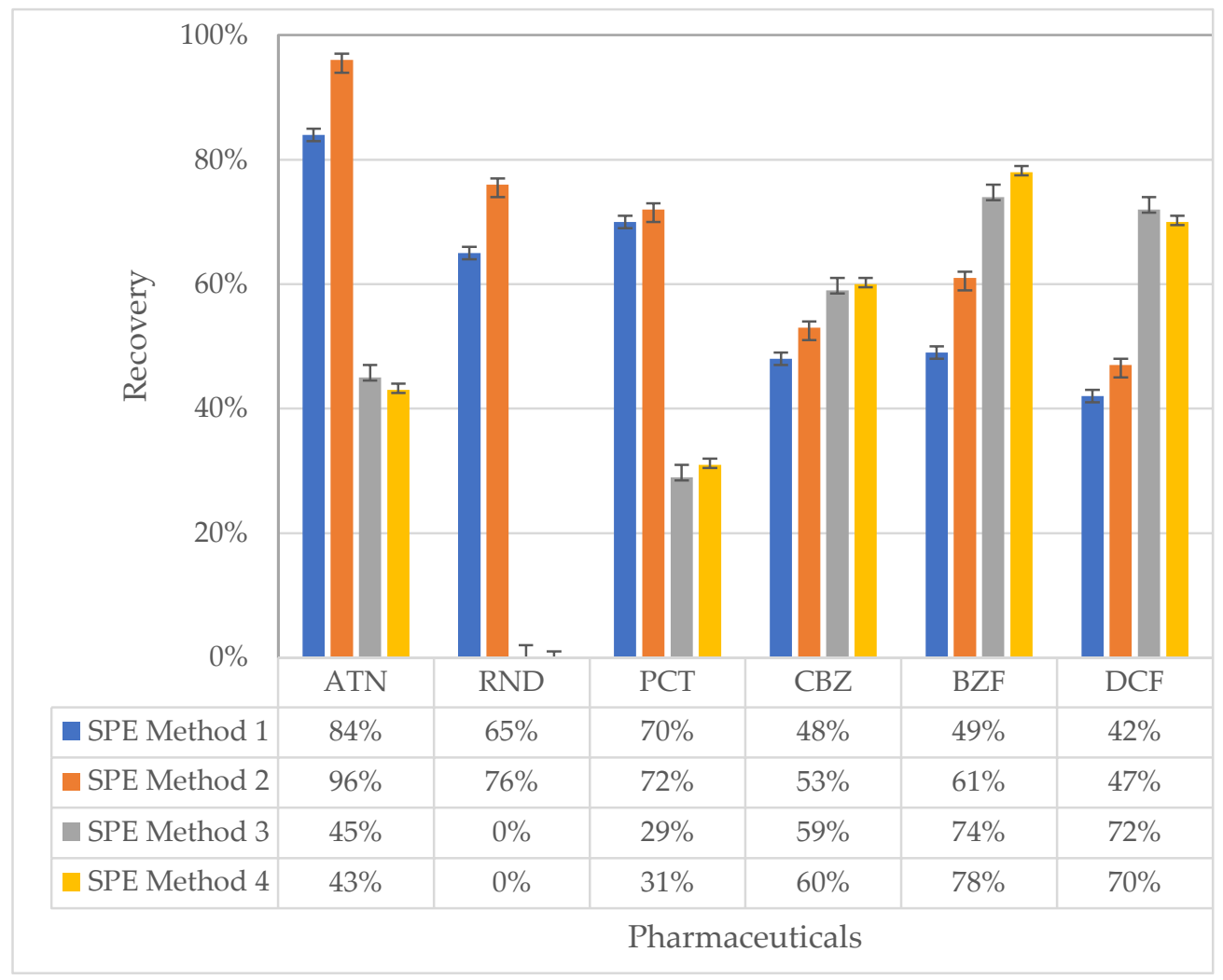

Figure 2. Recoveries for the extraction of selected pharmaceuticals in synthetic wastewater by using four different SPE methods.

While ranitidine can be extracted by HLB OASIS, no recoveries were observed by C18 cartridges. For atenolol, HLB OASIS (higher than $86 \%$ ) gave better recoveries than did C18 cartridges (approximately 45\%). Similarly, HLB OASIS was more efficient (70\%) than C18 for paracetamol. Oasis HLB provided better results for atenolol, paracetamol, and ranitidine compared to those for Isolute C18, while Isolute C18 provided better results for carbamazepine, bezafibrate, and diclofenac compared to those of Oasis HLB. The recoveries were 60,78 , and $70 \%$ with the SPE method 4 for carbamazepine, bezafibrate, and diclofenac, respectively. Accordingly, SPE method 1 was chosen for the analysis of atenolol, ranitidine, and paracetamol, and SPE method 4 was chosen for the analysis of carbamazepine, bezafibrate, and diclofenac for all the analyses in this study. 


\subsection{Effect of SRT on COD Removal and MLSS Concentration}

The bioreactor shown in Figure 1 was filled with aerobic activated sludge brought from the Atakoy Wastewater Treatment Plant in Istanbul. The reactor was operated at hydraulic retention time (HRT) $(17.7 \mathrm{~h})$, which corresponds to a permeate flux of $10 \mathrm{~L} / \mathrm{m}^{2} \cdot \mathrm{h}$.

During the time to reach the steady-state, the reactor was fed with synthetic domestic wastewater without MPs. After reaching a steady-state, the addition of MPs was started. All SRT studies were evaluated separately, and for each of them, the reactor was prepared from the starting point to reach steady-state conditions. To evaluate the effect of sludge retention time on COD degradation and bacterial growth, the reactor was controlled for 96 days after it reached steady-state conditions. The results of mixed liquor suspended solids (MLSS), mixed liquor volatile suspended solids (MLVSS) and, COD are seen in Figures 3 and 4, respectively.

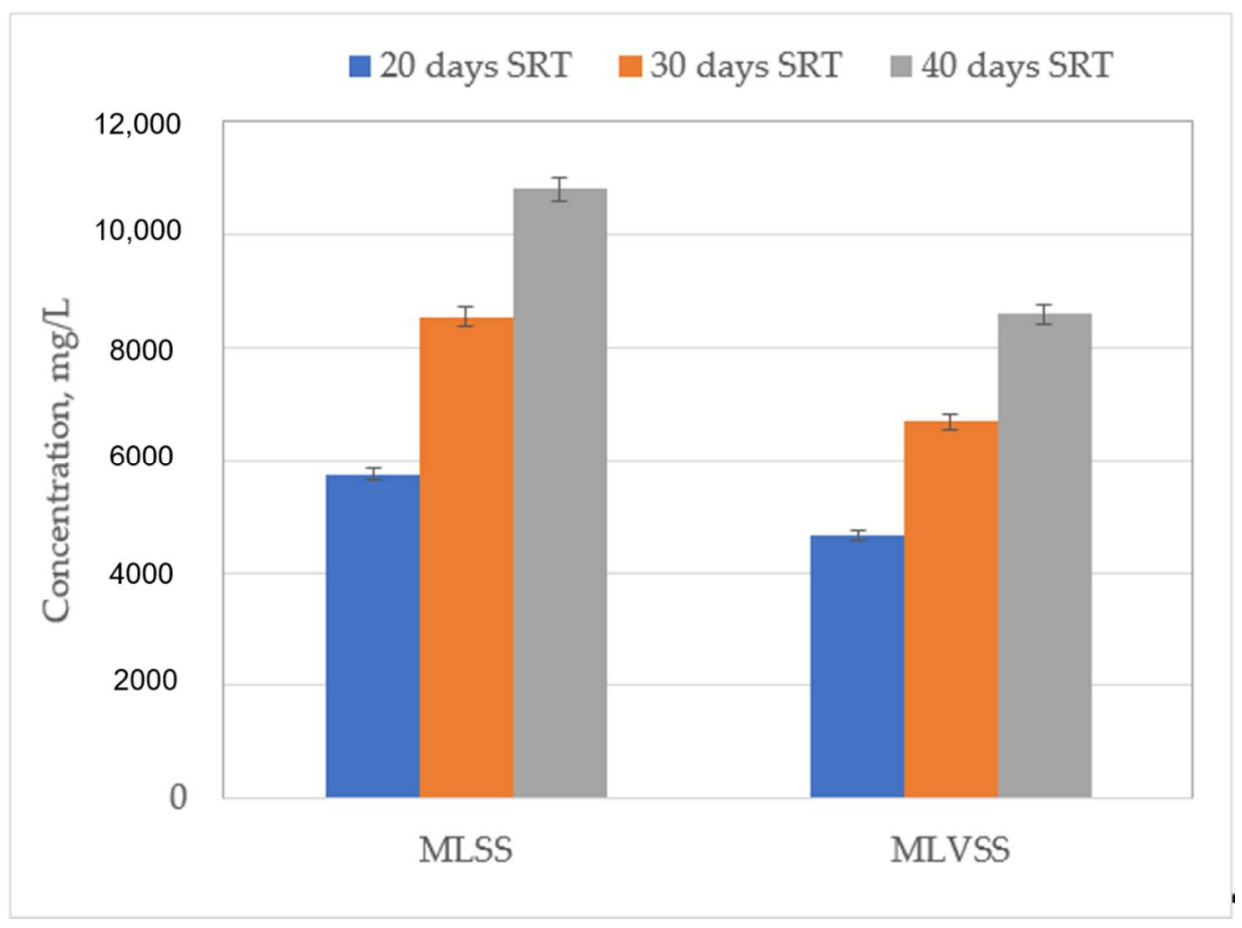

Figure 3. The average of MLSS and MLVSS concentrations in different solid retention times (SRTs).

During the 20-day SRT, the COD removal efficiency for the $0.45 \mu \mathrm{m}$ membrane was between 93.1 and $93.5 \%$, and for $0.20 \mu \mathrm{m}$ membrane it was $94.2-94.5 \%$ (Figure 4 ). In addition, the MLSS values ranged between 5492 and $5870 \mathrm{mg} / \mathrm{L}$, and the MLVSS varied between 4514 and $4872 \mathrm{mg} / \mathrm{L}$ (Figure 3). Similarly, at 30 days of SRT, COD removal efficiencies increased slightly $(95.6-95.9 \%$ for the $0.45 \mu \mathrm{m}$ membrane and $96.3-96.7 \%$ for the $0.2 \mu \mathrm{m}$ membrane), however, MLSS and MLVSS concentrations were 1.5 times higher than the results of the 20-day SRT. Conversely, the improvements in COD removal efficiencies were much higher and were $97.3-97.7 \%$ and $98.0-98.2 \%$ for the 0.45 and $0.2 \mu \mathrm{m}$ membranes at 40-day SRT, respectively. The MLSS and MLVSS increased by approximately 2 times those of the 20-day SRT. These results are indeed comparable with the study of Broeck et al. (2012) who reported that increasing SRT increases the concentration of sludge solids and a longer SRT boosts COD removal treatment efficiency and produces less sludge [23].

Because of the high SRT values and complete solid retention inside the MBR, the biodiversity of the microorganisms is promoted and even slowly growing and free-living bacteria remain in the reactor, which leads to better performance [24]. 

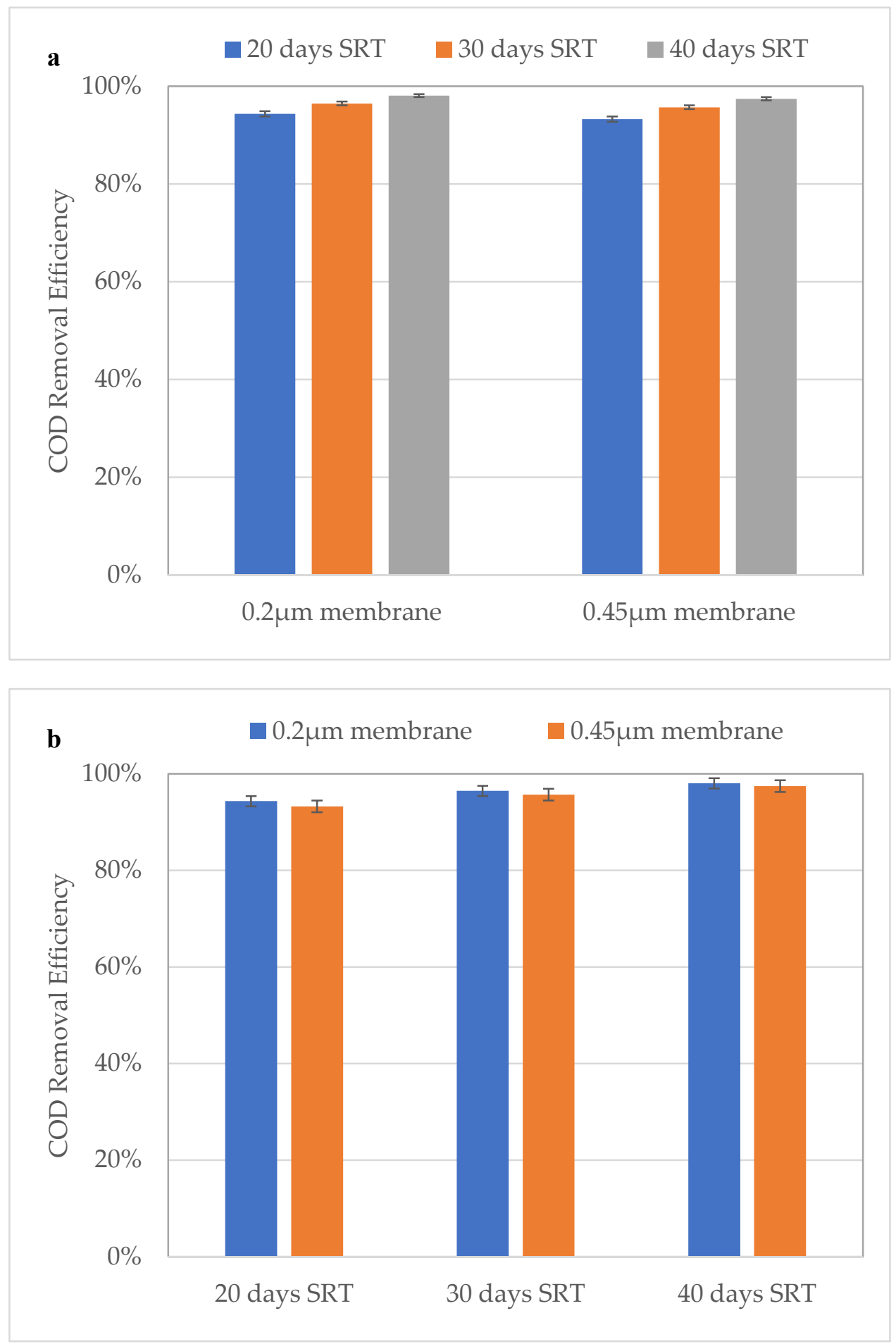

Figure 4. COD removal efficiency based on membrane type (a) and different SRTs (b).

\subsection{Effect of SRT on the Removal of MPS}

During the acclimatization phase, the reactor was fed with only synthetic domestic wastewater and when the reactor reached steady-state conditions, the mixture of atenolol, ranitidine, paracetamol, carbamazepine, bezafibrate, and diclofenac was pumped with a feed pump shown in Figure 1. The removal was monitored for 1 week and the samples were collected accordingly for 20, 30, and 40-day SRT. The results are given in Table 3 in detail, and in Figure 5 the removal efficiencies are shown for different SRTs passed through the $0.2 \mu \mathrm{m}$ and $0.45 \mu \mathrm{m}$ membranes-equipped MBR system. The increase in MLSS and MLVSS 
is recognized as one of the most important parameters promoting the biodegradation of pharmaceuticals and personal care products (PPCPs) [25]. According to these results, the 40-day SRT was selected as the best condition for the steady-state conditions. The concentrations, standard deviations, LOD, and LOQ of the studied compounds can be found in Table 3, and the comparison of the removal efficiencies of all compounds is given in Figure 5.
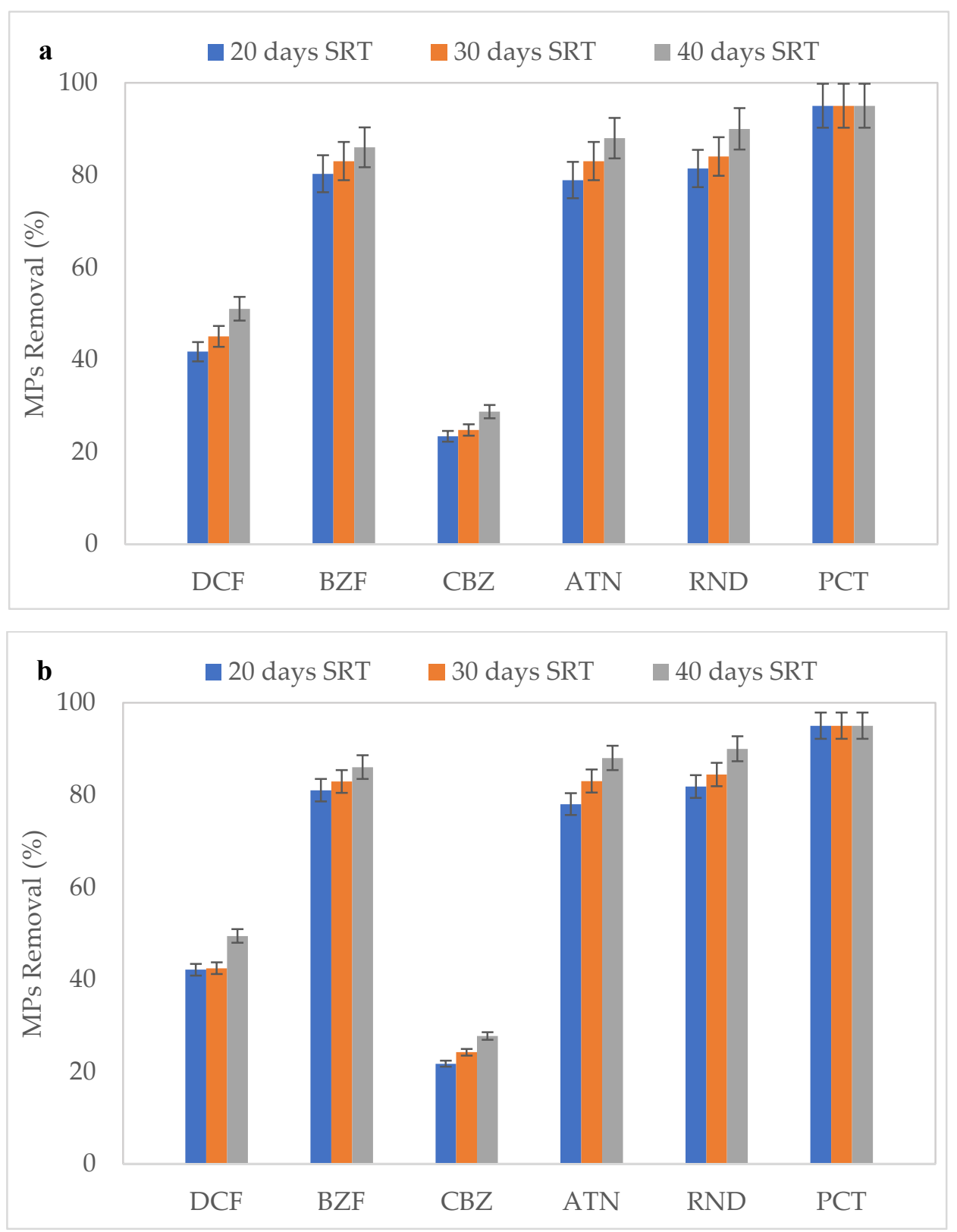

Figure 5. Micropollutants (MPs) removal under different SRTs in the membrane bioreactor (MBR) system equipped with (a) $0.2 \mu \mathrm{m}$ and (b) $0.45 \mu \mathrm{m}$ membranes (DCF: Diclofenac, BZF: Bezafibrate, CBZ: Carbamazepine, ATN: Atenolol, RND: Ranitidine, PCT: Paracetamol). 
Table 3. The concentrations of pharmaceuticals before and after biodegradation.

\begin{tabular}{|c|c|c|c|c|c|c|c|c|c|c|c|c|c|c|c|c|c|c|c|c|c|c|c|c|}
\hline \multirow[b]{2}{*}{ Comp. } & \multirow[b]{2}{*}{$\mathrm{R}^{2}$} & \multirow[b]{2}{*}{ LOD } & \multirow[b]{2}{*}{ LOQ } & \multicolumn{7}{|c|}{ 40-Day SRT } & \multicolumn{7}{|c|}{ 30-Day SRT } & \multicolumn{7}{|c|}{ 20-Day SRT } \\
\hline & & & & Inf. & $\begin{array}{c}0.2 \mu \mathrm{m} \\
\text { mem. MBR } \\
\text { Eff. }\end{array}$ & $\begin{array}{l}\text { RSD\% } \\
(n=3)\end{array}$ & R.E. \% & $\begin{array}{c}0.45 \mu \mathrm{m} \\
\text { mem. MBR } \\
\text { Eff. }\end{array}$ & $\begin{array}{l}\text { RSD \% } \\
(n=3)\end{array}$ & R.E.\% & Inf. & $\begin{array}{c}0.2 \mu \mathrm{m} \\
\text { mem. MBR } \\
\text { Eff. }\end{array}$ & $\begin{array}{l}\text { RSD } \% \\
(n=3)\end{array}$ & R.E.\% & $\begin{array}{c}0.45 \mu \mathrm{m} \\
\text { mem. MBR } \\
\text { Eff. }\end{array}$ & $\begin{array}{l}\text { RSD \% } \\
(n=3)\end{array}$ & R.E\% & Inf. & $\begin{array}{c}0.2 \mu \mathrm{m} \\
\text { mem. MBR } \\
\text { Eff. }\end{array}$ & $\begin{array}{l}\text { RSD \% } \\
(n=3)\end{array}$ & R.E\% & $\begin{array}{l}0.45 \mu \mathrm{m} \\
\text { mem. MBR } \\
\text { Eff. }\end{array}$ & $\begin{array}{l}\text { RSD } \% \\
(n=3)\end{array}$ & R.E\% \\
\hline DCF & 0.997 & 1.3 & 4.39 & $20.76 \pm 0.11$ & $10.173 \pm 0.19$ & 1.875 & 51 & $10.49 \pm 0.38$ & 3.713 & 49.4 & $20.48 \pm 0.34$ & $11.23 \pm 0.17$ & 1.496 & 45 & $11.8 \pm 0.16$ & 1.4 & 42.4 & $20.82 \pm 0.23$ & $12.13 \pm 0.16$ & 1.281 & 41.7 & $12.05 \pm 0.134$ & 1.112 & 42.1 \\
\hline BZF & 0.997 & 0.134 & 0.445 & $12.48 \pm 0.21$ & $1.72 \pm 0.01$ & 0.723 & 86 & $1.75 \pm 0.02$ & 1.4 & 86 & $12.44 \pm 0.18$ & $2.093 \pm 0.01$ & 0.225 & 83 & $2.126 \pm 0.038$ & 1.814 & 82.9 & $12.31 \pm 0.15$ & $2.43 \pm 0.01$ & 0.455 & 80.26 & $2.34 \pm 0.025$ & 0.752 & 81 \\
\hline $\mathrm{CBZ}$ & 0.991 & 1.17 & 3.9 & $12.583 \pm 0.15$ & $8.96 \pm 0.1$ & 1.112 & 28.7 & $9.09 \pm 0.08$ & 0.933 & 27.7 & $12.693 \pm 0.15$ & $9.55 \pm 0.15$ & 1.539 & 24.7 & $9.62 \pm 0.237$ & 2.466 & 24.2 & $12.428 \pm 0.17$ & $9.529 \pm 0.09$ & 0.891 & 23.32 & $9.731 \pm 0.067$ & 0.688 & 21.7 \\
\hline ATN & 0.992 & 0.64 & 2.13 & $20.81 \pm 0.12$ & $2.41 \pm 0.04$ & 1.79 & 88 & $2.51 \pm 0.06$ & 2.28 & 88 & $20.87 \pm 0.04$ & $3.52 \pm 0.03$ & 0.877 & 83 & $3.5 \pm 0.054$ & 1.55 & 83 & $20.81 \pm 0.26$ & $4.385 \pm 0.02$ & 0.522 & 78.9 & $4.58 \pm 0.037$ & 0.814 & 78 \\
\hline RND & 0.997 & 0.665 & 2.22 & $20.48 \pm 0.07$ & $2.02 \pm 0.03$ & 1.4 & 90 & $2.028 \pm 0.05$ & 2.43 & 90 & $20.6 \pm 0.27$ & $3.28 \pm 0.03$ & 0.995 & 84 & $3.21 \pm 0.088$ & 2.77 & 84.4 & $20.52 \pm 0.18$ & $3.81 \pm 0.01$ & 0.228 & 81.4 & $3.73 \pm 0.012$ & 0.342 & 81.8 \\
\hline PCT & 0.999 & 5.3 & 17.7 & $103.96 \pm 0.81$ & n.d & & $\geq 95$ & n.d & & $\geq 95$ & $104.033 \pm 1.95$ & n.d & & $\geq 95$ & n.d & & $\geq 95$ & $103.247 \pm 1.26$ & n.d & & $\geq 95$ & n.d & & $\geq 95$ \\
\hline
\end{tabular}

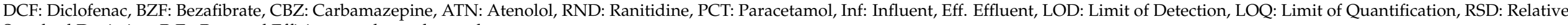
Standard Deviation, R.E.: Removal Efficiency. n.d: not detected. 
Paracetamol was detected as under the limit of detection at the 20,30, and 40-day SRT, and according to LOD, paracetamol concentrations were obtained lower than $5.3 \mu \mathrm{g} / \mathrm{L}$ for all conditions. Even the highest concentration within all selected MPs was paracetamol $(100 \mu \mathrm{g} / \mathrm{L})$, the highest removal efficiency was obtained for paracetamol for all SRTs. The lowest removal efficiency was observed for carbamazepine for both membranes (approximately 28\%) regardless of varying SRTs. This low removal efficiency was also observed by the authors of [25]. The diclofenac removal efficiency was observed at approximately 50\%, which was similar to the study conducted by Mousel et al. (2021) [26] who studied the ultrafiltration membrane bioreactor (UF-MBR) process in the degradation of several pharmaceuticals from raw hospital wastewater and found that the removal of antiinflammatory drugs (ibuprofen and paracetamol) was highly efficient. Paracetamol was the most removed compound followed by ranitidine, atenolol, bezafibrate, diclofenac, and carbamazepine for both membranes. These results align with many previous works [27,28]. It can be concluded that the MBR treatment with several SRT conditions can remove some of the MPs at high removal efficiencies, however, a further treatment process is required for total removal.

The concentration of all studied compounds was decreased with the increase of SRT. It can be observed in Figure 3 that MLSS showed an increase in concentration with the increase of SRT. The increase in MLSS should assist the sorption of selected pharmaceuticals [25,29]. While the increased SRT can generally boost the biological variety of slowly growing bacteria and longer sludge retention promotes the removal of MPs, some researchers have reported that diclofenac and carbamazepine removal is not affected significantly by SRT changes in MBR treatment [30].

\subsection{Removal Mechanism and Possible Pathways}

The pharmaceutical removal mechanisms in MBR treatment are complex and characterized by four main routes: (i) biotransformation or degradation; (ii) sorption by the sludge; (iii) volatilization or aeration striping; and, (iv) physical removal through membranes [30]. The constant of Henry's Law for selected pharmaceuticals is lower than $<10^{-6}$, which shows the removal of these compounds by volatilization is negligible (Table 1). Moreover, microfiltration (MF) membranes usually have a molecular weight cut off (MWCO) above several thousand daltons $(\mathrm{Da})$, so that pharmaceutical retention (MWCO from 150 up to $350 \mathrm{Da}$ ) is insignificant in the MBR processes because of the exclusion of size. Consequently, biotransformation and sorption by sludge were presumably the dominating removing mechanisms.

For non-ionizable compounds, the hydrophobicity is described as log Kow, while it is described as $\log \mathrm{D}$ for ionizable compounds; a compound is considered as hydrophobic when $\log \mathrm{D}>3.2$ or $\log$ Kow $>2$ [28]. The $\mathrm{pKa}$ values of bezafibrate and diclofenac are 3.61 and 4.15 , respectively, (Table 1) so they are ionizable compounds, whereas the other pharmaceuticals showed no ionization. Accordingly, all the pharmaceuticals used in this study can be considered hydrophilic except for carbamazepine, which is a moderate hydrophobic compound.

The increased removal efficiency of hydrophobic pharmaceuticals can be due to (i) the dominant sorption by the sludge, which results in enhanced biological degradation, and (ii) having only electron-donating groups (EDGs) that improve oxidation [30]. The removal of carbamazepine is low in MBR processes because of the lack of an electrondonating group. Many other studies have shown that carbamazepine is not removed and recalcitrated in treatment with MBR due to poor degradability [5,8]. On the other hand, diclofenac was reduced at relatively low efficiency with median removal efficiencies of $49.4 \%, 42.4 \%$, and $42.1 \%$ at SRTs of 40 days, 30 days, and 20 days, respectively. Other researchers have documented a slow or non-biotransformation rate of diclofenac [28,30]. The lower elimination rates of diclofenac and carbamazepine are due to the existence of multi-aromatic rings in their structure [11]. Paracetamol is highly degraded because its structure enables bacteria and enzymes to have unobstructed access to the exposed 
molecule that is later amended [31]. The removal of hydrophilic MPs ranged from low removal (diclofenac) to almost complete removal (paracetamol). The removal of hydrophilic MPs varies because MPs have different molecular structures and functional groups. Various removal efficiencies reported for hydrophilic MPs might be because (i) compounds having only EDGs could accomplish a high degree of removal; (ii) compounds with EDGs and e-withdrawing (EWGs) like amide and chloride in their molecular structure including paracetamol, diclofenac, and atenolol have diverse removal efficiencies; (iii) compounds that only have strong EWGs like carbamazepine showed low removal efficiency [30]. Therefore, the intrinsic biodegradability of these compounds has a great impact on the dominant removal mechanism of them, as the sludge sorption is less important.

The presence of possible by-products in the samples of the studies with an SRT period of 40 days and using a $0.2 \mu \mathrm{m}$ membrane was detected using LC/-MS-MS. Accordingly, there were no by-products detected for paracetamol, atenolol, and ranitidine. The reason could be that the possible by-products could not be concentrated by the method used for SPE. The possible by-products determined for bezafibrate, carbamazepine, and diclofenac are listed in Table 4.

Table 4. The possible by-products of diclofenac, bezafibrate, and carbamazepine that were detected [32-37].

\begin{tabular}{|c|c|c|c|c|}
\hline PPCPs & Transformation Products & $m / z$ & Structure & Formula \\
\hline \multirow[t]{2}{*}{ Diclofenac } & $\begin{array}{c}\text { DCF-TP1 } \\
\text { DCF-lactam or 1-(2,6-dichlorophenyl)- } \\
\text { 1,3-dihydro-2H-indol-2-one }\end{array}$ & 280.095 & & $\mathrm{C}_{14} \mathrm{H}_{10} \mathrm{NOCl}_{2}$ \\
\hline & $\begin{array}{c}\text { DCF-TP2 } \\
\text { DCF-benzoic acid }\end{array}$ & 283.036 & & $\mathrm{C}_{13} \mathrm{H}_{9} \mathrm{Cl}_{2} \mathrm{NO}_{2}$ \\
\hline Bezafibrate & 4-Chlorobenzoic acid & 113.05 & & $\mathrm{C}_{7} \mathrm{H}_{5} \mathrm{ClO}_{2}$ \\
\hline \multirow[t]{3}{*}{ Carbamazepine } & CBZ-TP1 & 253.097 & & $\mathrm{C}_{15} \mathrm{H}_{12} \mathrm{~N}_{2} \mathrm{O}_{2}$ \\
\hline & CBZ-TP2 & 210.015 & & $\mathrm{C}_{14} \mathrm{H}_{11} \mathrm{NO}$ \\
\hline & CBZ-TP3 & 224.125 & & $\mathrm{C}_{14} \mathrm{H}_{9} \mathrm{NO}_{2}$ \\
\hline
\end{tabular}

4-Chlorobenzoic acid was detected, which is the common metabolite for bezafibrate [32]. Furthermore, three possible by-products were determined for carbamazepine, which are named CBZ-TP1, CBZ-TP2, and CBZ-TP3, as given in Table 4. CBZ-TP1 could be formed by oxidation of the CBZ molecule $(m / z=253)$. Later CBZ-TP1 could form with the lost $-\mathrm{CONH}_{2}$ group and then form CBZ-TP2 and CBZ-TP3. The diclofenac compound also had some by-products that were observed in the activated sludge treatment processes. DCF-TP1 and DCF-TP2, which are DCF-lactam or 1-(2,6-dichlorophenyl)-1,3- 
dihydro-2H-indol-2-one and DCF-benzoic acid, were observed as given in Table 4 [33,34]. Microorganisms played a significant role in the transformation of carbamazepine, bezafibrate, and diclofenac by electrochemical reduction and oxidative transformation [35].

\subsection{Bacterial Community Analysis}

Inorganic and organic materials are oxidized by microorganisms in oxidation-reduction reactions to produce growth and maintenance energy. Under aerobic conditions, electron exchanges (food substrate for an organism) are often part of oxidation-reduction reactions and the electron acceptor is oxygen [38,39].

In this study, the 40-day SRT had the optimum performance in pharmaceuticals elimination and also in COD removal efficiency, so the metagenomic analysis was done for this period to understand the bacterial community before and after adding the pharmaceuticals.

Figure 6 shows the percentage of the microbial community at the phylum level inoculated in the aerobic MBR system of activated sludge, and the microbial community percentage for the same conditions at the class level is shown in Figure 7 at 0 days during the steady-state, which is the time before adding the pharmaceuticals, and also 96 days after adding the pharmaceuticals. As a result of the metagenomic analysis applied to this sample, a total of 23 phyla and 58 classes were identified. Based on 16S rRNA NGS data, the percentage of dominant microbial distributions in raw sludge were found to be $46.8 \%$ Proteobacteria, $14.3 \%$ Firmicutes, 9.2\% Actinobacteria, and 5.4\% Bacteroidetes. Proteobacteria represents the predominate heterotrophic bacterial phylum with Gammaproteobacteria, Betaproteobacteria, Deltaproteobacteria, and Alphaproteobacteria classes, the genus of these bacteria were identified to use paracetamol as the sole carbon and energy source [40]. It can be noticed that the Proteobacteria phylum was increased to $60.0 \%$ three months after adding the pharmaceuticals (Figure 5) and the Gammaproteobacteria class increased from $26 \%$ to $44 \%$ (Figure 6). The Actinobacteria class can metabolize paracetamol, carbamazepine, and atenolol, and it was also increased from $9.1 \%$ to $17.9 \%$ after adding pharmaceuticals [40].

In general, the key mechanism for the removal of pharmaceuticals by activated sludge is biodegradation. However, the elimination of environmental contaminants is not always successful due to the lack of degraders in the environment. Biological acclimation and bioaugmentation will overcome all these limitations [41]. Pure cultures and mixed cultures, which can remove the pollutants, can be dominated by biological acclimation and bioaugmentation in the biological treatment process. Pure cultures can be used to remove commonly detected carbamazepine, isolating it from the activated sludge, wastewater, or sediment. Pure carbamazepine has a stable structure leading to low biodegradability, however, two pure cultures will degrade carbamazepine in the presence of glucose: unidentified Basidiomycete [42], and Streptomyces MIUG [42,43]. White rot fungus Phanerochaete Sordida YK-624 can remove diclofenac entirely and in the absence of extra substrate can eliminate its lethal toxicity to organisms [41-43]. 

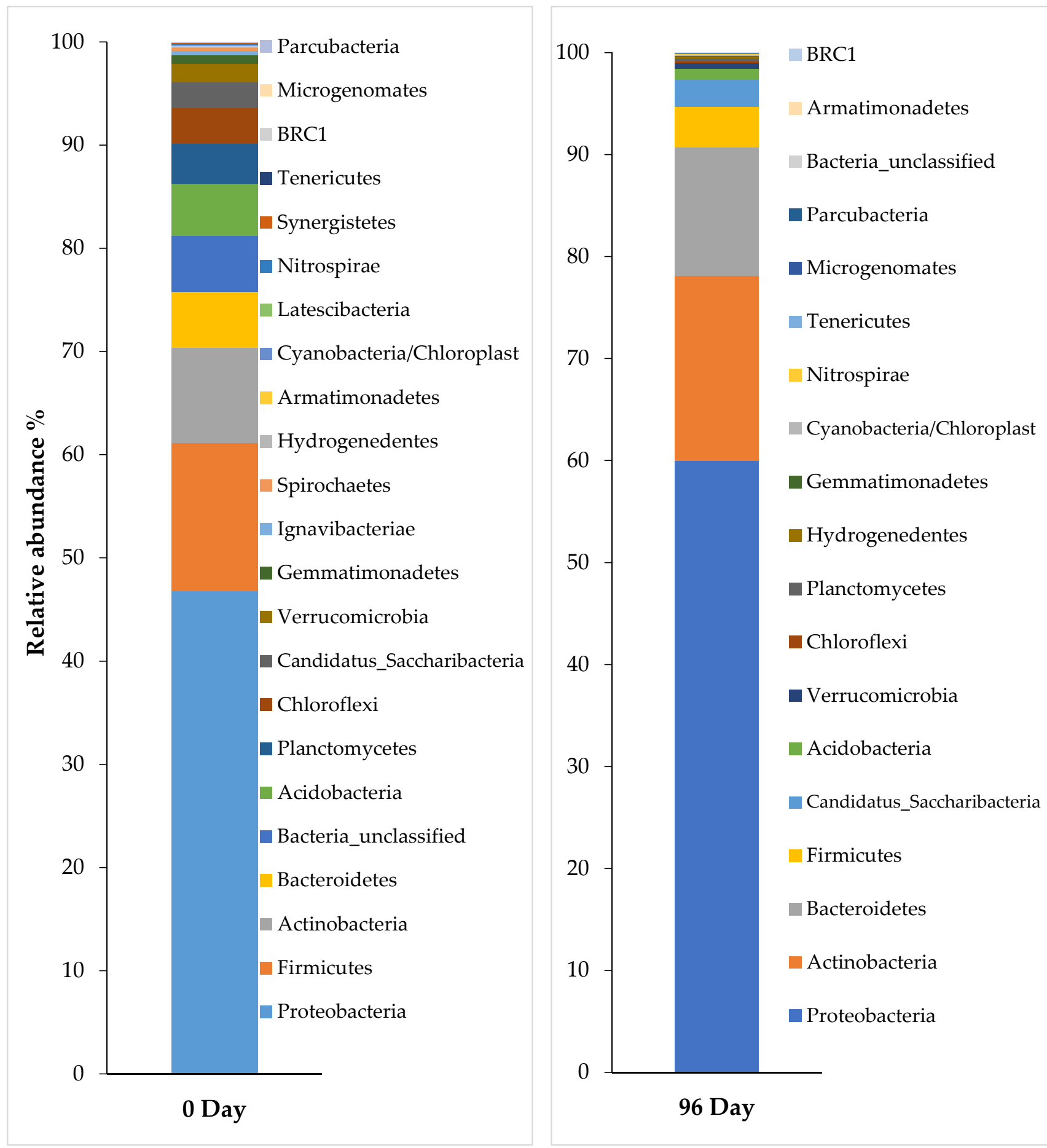

Figure 6. Profiles of bacterial community composition at the phylum level of activated sludge before (at 0 day-left) and after adding pharmaceuticals (at 96 day-right) in 40-day SRT. 


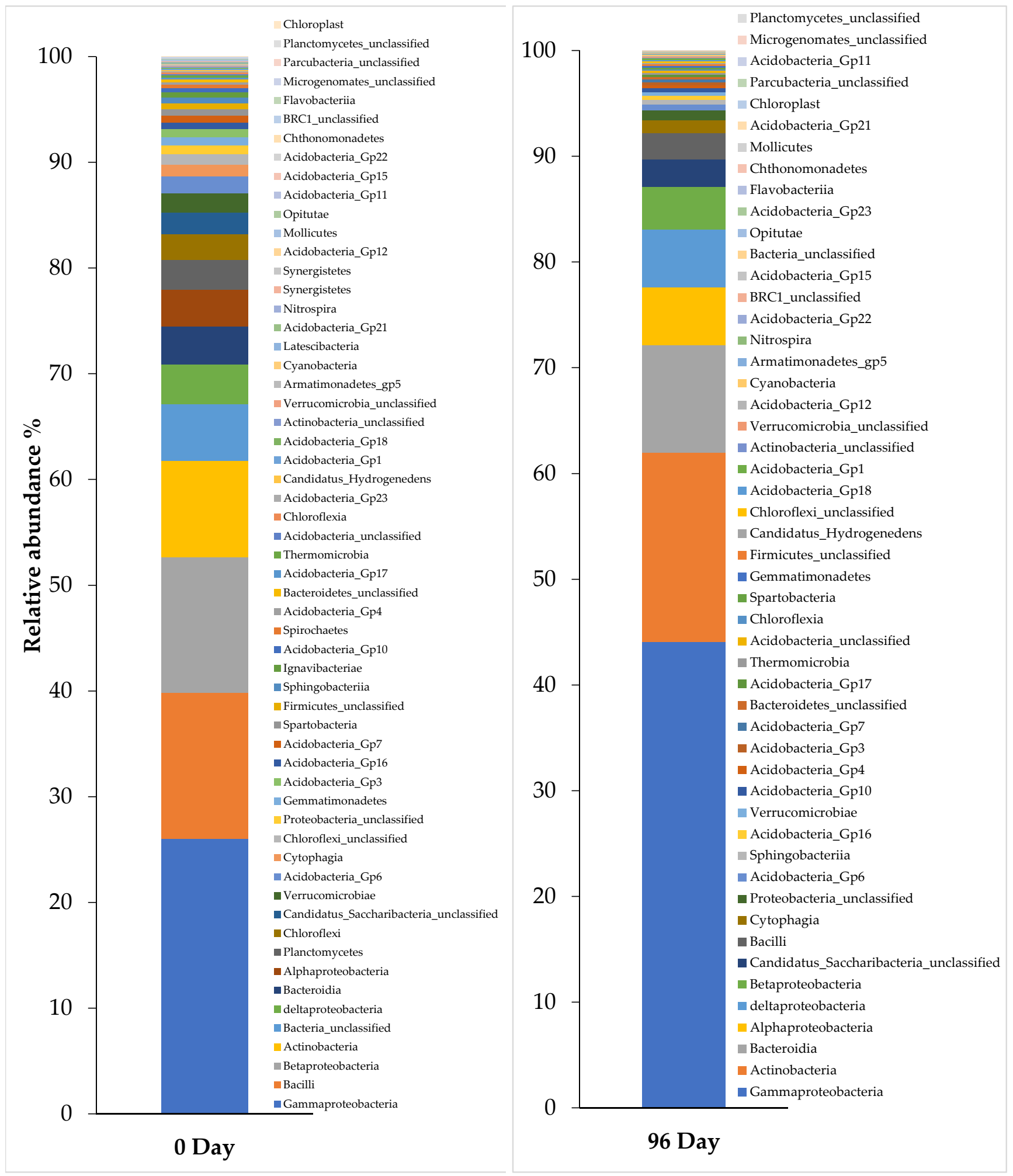

Figure 7. Profiles of bacterial community composition at the class level of activated sludge before (at 0 day-left) and after adding pharmaceuticals (at 96 day-right) in 40-day SRT.

\section{Conclusions}

The biodegradation of six pharmaceuticals was investigated in a membrane bioreactor. After the reactor reached the steady-state condition, the degradation efficiencies of six targeted pharmaceuticals were determined under different sludge retention times. The 
highest degradation efficiencies were observed for paracetamol for each SRT followed by paracetamol, ranitidine, atenolol, bezafibrate, diclofenac, and carbamazepine. The bacterial community analysis was evaluated for the sludge in steady-state conditions and also after adding the pharmaceuticals. It was observed that Proteobacteria in the sludges increased from $46.8 \%$ to $60 \%$ while Actinobacteria increased from $9.1 \%$ to $17.9 \%$. This reveals that microorganisms can metabolize the targeted pharmaceuticals. To understand the degradation mechanism, possible by-products were observed in the effluent samples, where the first-step degradation by-products of diclofenac, bezafibrate, and carbamazepine were detected. As a further study, the ratio of sludge adsorption and degradation of targeted pharmaceuticals can be studied to better understand whether the sludge requires additional treatment. Since the degradation of diclofenac and carbamazepine was low and they need to be degraded to reach the non-cancerogenic limits, the development of highly effective biodegradation of these compounds should also be a future focus.

Author Contributions: Conceptualization, R.A.K.A.; Funding acquisition, R.A.K.A.; Investigation, R.A.K.A., K.U.-A., R.K.S.M., and N.M.-D.; Methodology, R.A.K.A., K.U.-A., and R.K.S.M.; Project administration, R.A.K.A. and O.C.; Supervision, O.C.; Writing-Original draft, R.A.K.A., K.U.-A., and R.K.S.M.; Writing-Review and editing, R.A.K.A., K.U.-A., N.M.-D., and O.C. All authors have read and agreed to the published version of the manuscript.

Funding: This study was conducted in 2019 and funded by Yildiz Technical University Scientific Research Projects Coordination Unit. Project Number: FDK-2018-3276.

Institutional Review Board Statement: Not applicant.

Informed Consent Statement: Not applicant.

Data Availability Statement: All data are included in the article. Data sharing is not applicable to this article.

Conflicts of Interest: The authors declare no conflict of interest.

\section{References}

1. Kondor, A.C.; Jakab, G.; Vancsik, A.; Filep, T.; Szeberényi, J.; Szabó, L.; Maász, G.; Ferincz, Á.; Dobosy, P.; Szalai, Z. Occurrence of pharmaceuticals in the Danube and drinking water wells: Efficiency of riverbank filtration. Environ. Pollut. 2020, $265,114893$. [CrossRef]

2. Van Driezum, I.H.; Derx, J.; Oudega, T.J.; Zessner, M.; Naus, F.L.; Saracevic, E.; Kirschner, A.K.; Sommer, R.; Farnleitner, A.H.; Blaschke, A.P. Spatiotemporal resolved sampling for the interpretation of micropollutant removal during riverbank filtration. Sci. Total Environ. 2019, 649, 212-223. [CrossRef]

3. Kruglova, A.; Kråkström, M.; Riska, M.; Mikola, A.; Rantanen, P.; Vahala, R.; Kronberg, L. Comparative study of emerging micropollutants removal by aerobic activated sludge of large laboratory-scale membrane bioreactors and sequencing batch reactors under low-temperature conditions. Bioresour. Technol. 2016, 214, 81-88. [CrossRef] [PubMed]

4. Marszałek, A.; Bohdziewicz, J.; Puszczało, E. Co-Treatment of Municipal Landfill Leachate with Dairy Wastewater in Membrane Bioreactor. Ecol. Chem. Eng. S 2020, 27, 139-149. [CrossRef]

5. Taheran, M.; Brar, S.K.; Verma, M.; Surampalli, R.; Zhang, T.; Valero, J. Membrane processes for removal of pharmaceutically active compounds (PhACs) from water and wastewaters. Sci. Total Environ. 2016, 547, 60-77. [CrossRef]

6. Luo, Y.; Jiang, Q.; Ngo, H.H.; Nghiem, L.D.; Hai, F.I.; Price, W.E.; Wang, J.; Guo, W. Evaluation of micropollutant removal and fouling reduction in a hybrid moving bed biofilm reactor-membrane bioreactor system. Bioresour. Technol. 2015, 191, 355-359. [CrossRef]

7. Nguyen, L.N.; Hai, F.I.; Kang, J.; Nghiem, L.D.; Price, W.E.; Guo, W.; Ngo, H.H.; Tung, K.-L. Comparison between sequential and simultaneous application of activated carbon with membrane bioreactor for trace organic contaminant removal. Bioresour. Technol. 2013, 130, 412-417. [CrossRef] [PubMed]

8. Goswami, L.; Kumar, R.V.; Borah, S.N.; Manikandan, N.A.; Pakshirajan, K.; Pugazhenthi, G. Membrane bioreactor and integrated membrane bioreactor systems for micropollutant removal from wastewater: A review. J. Water Process. Eng. 2018, 26, 314-328. [CrossRef]

9. Kamaz, M.; Wickramasinghe, S.R.; Eswaranandam, S.; Zhang, W.; Jones, S.M.; Watts, M.J.; Qian, X. Investigation into Micropollutant Removal from Wastewaters by a Membrane Bioreactor. Int. J. Environ. Res. Public Health 2019, 16, 1363. [CrossRef]

10. Kamaz, M.; Jones, S.M.; Qian, X.; Watts, M.J.; Zhang, W.; Wickramasinghe, S.R. Atrazine Removal from Municipal Wastewater Using a Membrane Bioreactor. Int. J. Environ. Res. Public Health 2020, 17, 2567. [CrossRef] 
11. Cirja, M.; Ivashechkin, P.; Schäffer, A.; Corvini, P.F.X. Factors affecting the removal of organic micropollutants from wastewater in conventional treatment plants (CTP) and membrane bioreactors (MBR). Rev. Environ. Sci. Biotechnol. 2007, 7, 61-78. [CrossRef]

12. Dogan, A.; Płotka-Wasylka, J.; Kempińska-Kupczyk, D.; Namieśnik, J.; Kot-Wasik, A. Detection, identification and determination of chiral pharmaceutical residues in wastewater: Problems and challenges. TRAC Trends Anal. Chem. 2020, 122, 115710. [CrossRef]

13. Butkovskyi, A.; Leal, L.H.; Zeeman, G.; Rijnaarts, H. Micropollutants in source separated wastewater streams and recovered resources of source separated sanitation. Environ. Res. 2017, 156, 434-442. [CrossRef] [PubMed]

14. Beijer, K.; Björlenius, B.; Shaik, S.; Lindberg, R.H.; Brunström, B.; Brandt, I. Removal of pharmaceuticals and unspecified contaminants in sewage treatment effluents by activated carbon filtration and ozonation: Evaluation using biomarker responses and chemical analysis. Chemosphere 2017, 176, 342-351. [CrossRef] [PubMed]

15. Gallardo-Altamirano, M.; Maza-Márquez, P.; Peña-Herrera, J.; Rodelas, B.; Osorio, F.; Pozo, C. Removal of anti-inflammatory/analgesic pharmaceuticals from urban wastewater in a pilot-scale $\mathrm{A} 2 \mathrm{O}$ system: Linking performance and microbial population dynamics to operating variables. Sci. Total Environ. 2018, 643, 1481-1492. [CrossRef] [PubMed]

16. Botero-Coy, A.; Martínez-Pachón, D.; Boix, C.; Rincón, R.; Castillo, N.; Arias-Marín, L.; Manrique-Losada, L.; Torres-Palma, R.; Moncayo-Lasso, A.; Hernández, F. 'An investigation into the occurrence and removal of pharmaceuticals in Colombian wastewater'. Sci. Total Environ. 2018, 642, 842-853. [CrossRef] [PubMed]

17. Gros, M.; Petrović, M.; Barceló, D. Development of a multi-residue analytical methodology based on liquid chromatographytandem mass spectrometry (LC-MS/MS) for screening and trace level determination of pharmaceuticals in surface and wastewaters. Talanta 2006, 70, 678-690. [CrossRef]

18. Kumar, R.; Sarmah, A.K.; Padhye, L.P. Fate of pharmaceuticals and personal care products in a wastewater treatment plant with parallel secondary wastewater treatment train. J. Environ. Manag. 2019, 233, 649-659. [CrossRef]

19. Lahti, M. The Fate Aspects of Pharmaceuticals in the Environment: Biotransformation, Sedimentation and Exposure of Fish; University of Jyväskylä: Jyväskylä, Finland, 2012.

20. APHA; AWWA. Standard Methods for the Examination of Water and Wastewater, 22th ed.; APHA: Washington, DC, USA, 2012.

21. Bozcal, E.; Dagdeviren, M. Bacterial metagenome analysis of Mytilus galloprovincialis collected from Istanbul and Izmir coastal stations of Turkey. Environ. Monit. Assess. 2020, 192, 1-18. [CrossRef]

22. Edgar, R.C.; Haas, B.J.; Clemente, J.C.; Quince, C.; Knight, R. UCHIME Improves Sensitivity and Speed of Chimera Detection. Bioinformatics 2011, 27, 2194-2200. [CrossRef] [PubMed]

23. Broeck, R.V.D.; Van Dierdonck, J.; Nijskens, P.; Dotremont, C.; Krzeminski, P.; Van Der Graaf, J.; Van Lier, J.; Van Impe, J.; Smets, I. The influence of solids retention time on activated sludge bioflocculation and membrane fouling in a membrane bioreactor (MBR). J. Membr. Sci. 2012, 401-402, 48-55. [CrossRef]

24. Delgado, S.; Villarroel, R.; Gonzalez, E.; Morales, M. Aerobic Membrane Bioreactor for Wastewater Treatment-Performance Under Substrate-Limited Conditions. Biomass Detect. Prod. Usage 2011. [CrossRef]

25. Chtourou, M.; Mallek, M.; Dalmau, M.; Mamo, J.; Santos-Clotas, E.; Ben Salah, A.; Walha, K.; Salvadó, V.; Monclús, H. Triclosan, carbamazepine and caffeine removal by activated sludge system focusing on membrane bioreactor. Process. Saf. Environ. Prot. 2018, 118, 1-9. [CrossRef]

26. Mousel, D.; Bastian, D.; Firk, J.; Palmowski, L.; Pinnekamp, J. Removal of pharmaceuticals from wastewater of health care facilities. Sci. Total Environ. 2021, 751, 141310. [CrossRef] [PubMed]

27. Kim, M.; Guerra, P.; Shah, A.; Parsa, M.; Alaee, M.; Smyth, S.A. Removal of pharmaceuticals and personal care products in a membrane bioreactor wastewater treatment plant. Water Sci. Technol. 2014, 69, 2221-2229. [CrossRef]

28. Trinh, T.; Akker, B.V.D.; Coleman, H.M.; Stuetz, R.M.; Drewes, J.E.; Le-Clech, P.; Khan, S.J. Seasonal variations in fate and removal of trace organic chemical contaminants while operating a full-scale membrane bioreactor. Sci. Total Environ. 2016, 550, 176-183. [CrossRef]

29. Tiwari, B.; Sellamuthu, B.; Piché-Choquette, S.; Drogui, P.; Tyagi, R.D.; Vaudreuil, M.A.; Sauvé, S.; Buelna, G.; Dubé, R. Acclimatization of microbial community of submerged membrane bioreactor treating hospital wastewater. Bioresour. Technol. 2021, 319, 124223. [CrossRef]

30. Gurung, K.; Ncibi, M.C.; Sillanpää, M. Removal and fate of emerging organic micropollutants (EOMs) in municipal wastewater by a pilot-scale membrane bioreactor (MBR) treatment under varying solid retention times. Sci. Total Environ. 2019, 667, 671-680. [CrossRef]

31. Tambosi, J.L.; De Sena, R.F.; Favier, M.; Gebhardt, W.; José, H.J.; Schröder, H.F.; Moreira, R.D.F.P.M. Removal of pharmaceutical compounds in membrane bioreactors (MBR) applying submerged membranes. Desalination 2010, 261, 148-156. [CrossRef]

32. Quintana, J.B.; Weiss, S.; Reemtsma, T. Pathways and metabolites of microbial degradation of selected acidic pharmaceutical and their occurrence in municipal wastewater treated by a membrane bioreactor. Water Res. 2005, 39, 2654-2664. [CrossRef]

33. Vieno, N.; Sillanpää, M. Fate of diclofenac in municipal wastewater treatment plant-A review. Environ. Int. 2014, 69, 28-39. [CrossRef] [PubMed]

34. Vo, H.N.P.; Ngo, H.H.; Guo, W.; Nguyen, T.M.H.; Li, J.; Liang, H.; Deng, L.; Chen, Z. Poly-and perfluoroalkyl substances in water and wastewater: A comprehensive review from sources to remediation. J. Water Process. Eng. 2020, 36, 101393. [CrossRef]

35. Tahir, K.; Miran, W.; Nawaz, M.; Jang, J.; Shahzad, A.; Moztahida, M.; Kim, B.; Azam, M.; Jeong, S.E.; Jeon, C.O.; et al. Investigating the role of anodic potential in the biodegradation of carbamazepine in bioelectrochemical systems. Sci. Total Environ. 2019, 688, 56-64. [CrossRef] [PubMed] 
36. Wu, G.; Geng, J.; Shi, Y.; Wang, L.; Xu, K.; Ren, H. Comparison of diclofenac transformation in enriched nitrifying sludge and heterotrophic sludge: Transformation rate, pathway, and role exploration. Water Res. 2020, 184, 116158. [CrossRef] [PubMed]

37. Yao, M.; Duan, L.; Wei, J.; Qian, F.; Hermanowicz, S.W. Carbamazepine removal from wastewater and the degradation mechanism in a submerged forward osmotic membrane bioreactor. Bioresour. Technol. 2020, 314, 123732. [CrossRef]

38. Mhemid, R.K.S.; Akmirza, I.; Shihab, M.S.; Turker, M.; Alp, K. Ethanethiol gas removal in an anoxic bio-scrubber. J. Environ. Manag. 2019, 233, 612-625. [CrossRef]

39. Demir, M.N. Determination of microbial community in a pilot scale two-stage step-feed biological nutrient removal process. Glob. NEST J. 2019, 21, 211-221. [CrossRef]

40. Żur, J.; Piński, A.; Marchlewicz, A.; Hupert-Kocurek, K.; Wojcieszyńska, D.; Guzik, U. Organic micropollutants paracetamol and ibuprofen-Toxicity, biodegradation, and genetic background of their utilization by bacteria. Environ. Sci. Pollut. Res. 2018, 25, 21498-21524. [CrossRef]

41. Wang, J.; Wang, S. Removal of pharmaceuticals and personal care products (PPCPs) from wastewater: A review. J. Environ. Manag. 2016, 182, 620-640. [CrossRef]

42. Santos, I.J.S.; Grossman, M.J.; Sartoratto, A.; Ponezi, A.N.; Durrant, L.R. Degradation of the recalcitrant pharmaceuticals car-bamazepine and 17 $\alpha$-ethinylestradiol by ligninolytic fungi. Chem. Eng. 2012, 27, 169-174. [CrossRef]

43. Popa, C.; Favier, L.; Dinica, R.; Semrany, S.; Djelal, H.; Amrane, A.; Bahrim, G. Potential of newly isolated wild Streptomycesstrains as agents for the biodegradation of a recalcitrant pharmaceutical, carbamazepine. Environ. Technol. 2014, 35, 3082-3091. [CrossRef] [PubMed] 